\title{
Penerapan Metode Eksperimen untuk Meningkatkan Motivasi Belajar Siswa
}

\section{Fitran Sari}

Sekolah Menengah Pertama Negeri 3 Mataram, Jl. Niaga I/39, Pejanggik, Kec. Mataram, Kota Mataram, 83122, Indonesia

Email:fitransari@yahoo.com

$\begin{array}{ll}\text { ARTICLE INFO } & \text { ABSTRACT } \\ \text { Article history } & \text { [Title: The Implementation of Experiment Method to Improve Student's } \\ \text { Received: March } 2019 & \text { Learning Motivation]. The purpose of this study was to improve the learning } \\ \text { Revised: April } 2019 & \text { motivation of Learners of SMP Negeri } 3 \text { Mataram using the experimental method. This } \\ \text { Accepted: May } 2019 & \text { research is a classroom action research model of Kemmis and Taggart consisting of three } \\ \text { Published: June } 2019 & \text { cycles. The stages of each cycle consist of the planning stage, the stage of action, the stage } \\ \text { of observation, the stage of reflection. The research implementation subjects were class } & \text { VIII-3 students, amounting to } 29 \text { people on simple aircraft material. The results showed } \\ \text { Keywords } & \text { that students' learning motivation in the first cycle obtained an average score of } 56.25 \% \\ \text { experimental method; } & \text { consisting of } 50 \% \text { attention, relevance } 40 \%, \text { confidence } 75 \% \text { and satisfaction } 60 \% . \text { Cycle } \\ \text { learning motivation } & \text { II the average score of students is } 68.75 \% \text { consisting of } 72 \% \text { attention, } 78 \% \text { relevance, } \\ & \text { 60\% confidence and } 65 \% \text { satisfaction. The third cycle average score of } 83.27 \% \text { consisted } \\ & \text { of } 84.16 \% \text { attention, relevance } 80.68 \%, \text { confidence } 84.55 \% \text { and satisfaction } 83.55 \% . \\ & \text { From the results of this study, it can be concluded that the application of experimental } \\ \text { methods can increase students' learning motivation in class VIII-3 on Simple Plane } & \text { material. }\end{array}$

\begin{tabular}{ll} 
INFO ARTIKEL & ABSTRAK \\
\hline Sejarah Artikel & Tujuan penelitian ini untuk meningkatkan motivasi belajar siswa SMP Negeri 3 \\
Dikirim: Maret 2019 & Mataram menggunakan metode eksperimen. Penelitian ini merupakan \\
Direvisi: April 2019 & Penelitian Tindakan kelas model Kemmis dan Taggart yang terdiri dari 3 siklus. \\
Diterima: Mei 2019 & Adapun tahapan setiap siklus terdiri dari tahap perencanaan (planning), tahap \\
Dipublikasi: Juni 2019 & tindakan (action), tahap observasi (observation), tahap refleksi (reflection). Subyek \\
& implementasi penelitian adalah siswa kelas VIII-3 SMP yang berjumlah 29 orang \\
Kata kunci & pada materi pesawat sederhana. Hasil penelitian menunjukkan bahwa motivasi \\
metode eksperimen; & belajar siswa pada siklus I memperoleh rata-rata skor 56.25 \% terdiri dari \\
motivasi belajar & perhatian 50\%, relevansi 40\%, percaya diri 75\% dan kepuasan 60\%. Siklus II rata- \\
& rata skor siswa 68.75\% terdiri dari perhatian 72\%, relevansi 78\%, percaya diri \\
& 60\% dan kepuasan 65\%. Siklus III skor rata-rata 83.27\% terdiri dari perhatian \\
& 84.16\%, relevansi 80.68\%, percaya diri 84.55\% dan kepuasaan 83.55\%. Dari hasil \\
penelitian ini dapat disimpulkan bahwa penerapan metode eksperimen dapat & meningkatkan motivasi belajar siswa kelas VIII-3 pada materi Pesawat \\
& Sederhana.
\end{tabular}

How to Cite this Article? Sari, F. (2019). Penerapan Metode Eksperimen untuk Meningkatkan Motivasi Belajar Siswa. Jurnal Penelitian dan Pengkajian Ilmu Pendidikan: e-Saintika, 2(2), 7583.

\section{PENDAHULUAN}

Kualitas pendidikan Indonesia dianggap oleh banyak kalangan masih rendah. Hal ini dilihat dari beberapa indikator salah satunya adalah lulusan dari sekolah atau perguruan tinggi belum siap memasuki dunia kerja karena minimnya potensi 
yang dimiliki (Kunandar, 2007). Peningkatan mutu dan pemerataan guru dapat ditempuh melalaui program salah satunya adalah meningkatkan kualitas kurikulum dan pelaksanaan yang bertujuan membentuk karakter dan kecakapan hidup (life skill) sehingga siswa mampu memecahkan berbagai masalah kehidupan secara kreatif dan menjadi manusia yang inovatif serta produktif (Kunandar, 2007).

Hyman (1980) dikutip oleh Apriliya (2007) mengatakan bahwa iklim belajar yang kondusif dapat mendukung beberapa hal sebagai berikut:1) interaksi yang bermanfaat diantara siswa; 2) mempertegas pengalaman guru dan siswa; 3) menumbuhkan semangat yang memungkinkan kegiatan di kelas berlangsung dengan baik; dan 4) mendukung saling pengertian antar guru dan siswa. Sedangkan Walberg dalam Farley dan Gordon (1981) dikutip oleh Apriliya (2007) pun mengemukakan prestasi belajar siswa ditentukan oleh banyak faktor seperti usia, kemampuan dan motivasi, jumlah dan mutu pembelajaran serta lingkungan alami di rumah dan di kelas.

Pembelajaran mengupayakan munculnya usaha belajar dari siswa. Efektivitas pembelajaran yang dilakukan salah satu ditentukan oleh metode mengajar yang digunakan (Apriliya, 2007). Menurut Wardhana (2010) jika proses pembelajaran ingin berhasil dengan baik, yang pertama harus diperhatikan adalah metode atau pendekatan yang akan dilakukan sehingga sasaran yang diharapkan dapat tercapai atau terlaksana dengan baik. Metode atau cara pendekatan yang sesuai fungsinya merupakan alat untuk mencapai tujuan.

Salah satu metode mengajar adalah eksprimen yaitu cara penyajian pembelajaran dimana siswa melakukan percobaan dengan mengalami dan membuktikan sendiri sesuatu yang dipelajarinya (Juliansyah, 2010). Di dalam proses belajar mengajar dengan menggunakan metode percobaan ini, siswa diberi kesempatan untuk mengalami dan melakukan sendiri dengan melakukan suatu proses, mengamati suatu objek, menganalisis, membuktikan, dan menarik kesimpulan sendiri mengenai objek, keadaan, atau proses sesuatu (Apriliya, 2007). Hasil penelitian terkait model pembelajaran yang berorientasi pada kerjasama kelompok seperti metode eksperimen dinyatakan berpengaruh terhadap motivasi, hasil belajar (Sriwahyuningsih dkk, 2018), dan aktivitas siswa (Pour dkk., 2018) dalam pembelajaran.

Sekolah Menengah Pertama Negeri 3 Mataram memiliki 20 rombongan belajar. Kelas 9 terdiri dari 6 rombel, kelas VIII terdiri dari 6 rombel, kelas VII terdiri dari 6 rombel. Kelas VII dan VIII menggunakan kurikulum 2013. Dari 3 kelas VIII yang menjadi binaan, maka kelas VIII-3 memiliki motivasi belajar paling rendah begitu pula dengan kemampuan kognitif, namun siswa cukup rajin untuk mengikuti kegiatan pembelajan.

Hasil observasi awal terhadap kegiatan pembelajaran dengan wawancara dan pengamatan langsung pada saat kegiatan pembelajaran, motivasi belajar siswa masih tergolong rendah, ditemukan beberapa kendala yang muncul antara lain: 1) kegiatan pembelajaran tidak dapat dilaksanakan sesuai dengan alokasi waktu yang disediakan; 2) Konsentrasi belajar siswa masih tergolong rendah; 3) Aktivitas selama kegiatan pembelajaran berlangsung, yang aktif untuk belajar $\pm 5 \%$ dari keseluruhan siswa yang hadir di kelas sedangkan siswa yang lain dapat digolongkan dalam kondisi yang pasif. Terutama terlihat pada materi-materi yang 
memerlukan hitungan atau materi Fisika; 4) Fasilitas perpustakaan juga belum dipergunakan secara optimal. 5) Siswa tidak mempunyai buku penunjang untuk belajar. Ditinjau dari ratio jumlah buku dengan jumlah siswa adalah 1:2; 6) Selain itu dukungan dari lingkungan keluarga juga merupakan faktor lain yang mengurangi motivasi belajar.

Motivasi belajar awal siswa diukur juga dengan menggunakan angket motivasi belajar siswa terhadap mata pelajaran IPA. Hal ini dilakukan untuk menguatkan hasil pengamatan dan wawancara guru dengan siswa. Skor yang diperoleh rata-rata 55.68 \% ditinjau dari motivasi belajar terhadap mata pelajaran IPA. Skor rata-rata perolehan siswa disajikan pada Tabel 1.

Tabel 1. Observasi awal terhadap motivasi belajar siswa terhadap mata pelajaran IPA

\begin{tabular}{llc}
\hline No & \multicolumn{1}{c}{ Variabel } & Skor \\
\hline 1 & Ketekunan dalam belajar & $58.16 \%$ \\
2 & Ulet dalam menghadapi kesulitan & $37.94 \%$ \\
3 & Minat dan ketajaman perhatian dalam belajar & $49.14 \%$ \\
4 & Berpretasi dalam belajar & $82.76 \%$ \\
5 & Mandiri dalam belajar & $50.43 \%$ \\
\hline & Skor rata-rata & $55.68 \%$ \\
\hline
\end{tabular}

Berdasarkan Tabel 1. dapat dijelaskan bahwa keinginan siswa untuk berprestasi cukup tinggi yaitu $82.76 \%$ namun tidak diikuti oleh ketekunan dalam belajar, keuletan menghadapi kesulitan, minat dan ketajaman perhatian dalam belajar serta kemandirian dalam belajar, siswa hanya memperoleh skor tidak lebih dari 58\%. Sikap belajar dan perhatian ini yang menyebabkan siswa kesulitan dalam meningkatkan prestasi belajar. Berdasarkan uraian tersebut maka diadakan penelitian dengan judul "Penerapan Metode Eksperimen untuk Meningkatkan Motivasi Belajar Siswa.

\section{METODE}

Metode penelitian ini berisi jenis dan desain penelitian, subyek penelitian, instrumen pengumpulan data, dan teknik analisa data. Penelitian ini merupakan Penelitian Tindakan Kelas dengan model rancangan Kemmis dan Taggart dengan tiga siklus. Masing-masing siklus terdiri dari empat tahap yaitu Tahap penyusunan rencana tindakan, Tahap pelaksanaan tindakan, Tahap observasi, Tahap refleksi. Model rancangan penelitian dengan siklus diulang-ulang terus menerus sampai masalah yang diteliti dapat dipecahkan atau diatasi dengan baik. Model Kemmis dan Taggart digambarkan dalam bentuk spriral pada Gambar 1.

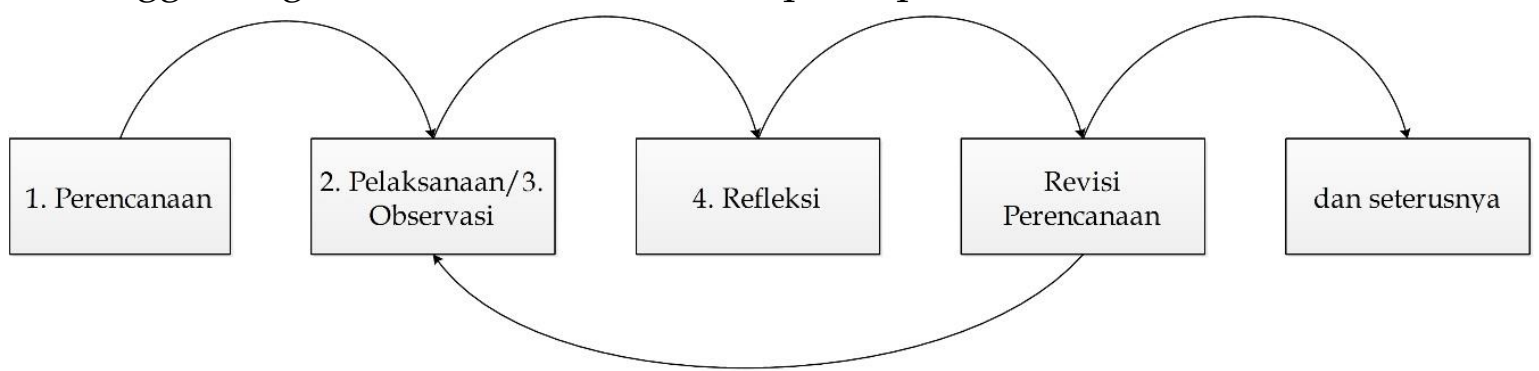

Gambar 1. Siklus dalam PTK menurut Kemmis dan Taggart 
Tahapan pada siklus I terdiri dari tahapan planning (perencanaan) meliputi: 1) mengidentifkasi hasil awal belajar siswa, 2) menyusun rencana pelaksanaan pembelajaran dengan metode eksperimen, 3) menyusun Lembar Kerja Siswa, 4) menyusun instrumen dan rubrik motivasi belajar, 5) membentuk kelompok yang heterogen baik kemampuan akademik maupun jenis kelamin.

Tahapan pelaksanaan tindakan, guru melaksanakan kegiatan sesuai dengan rencana pembelajaran yang telah disusun. Adapun langkah-langkah terdiri dari: 1) kegiatan pendahuluan, 2) kegiatan inti, dan, 3) kegiatan penutup. Kegiatan penutup diakhir pelaksanaan pembelajaran pada tiap siklus, guru mengevaluasi secara tertulis. Selain itu juga melakukan kegiatan repleksi serta penugasan.

Tahapan observasi dilakukan pengamatan selama proses pembelajaran berlangsung. Observer mencatat kegiatan yang terjadi dan mengisi lembar observasi baik angket motivasi belajar siswa maupun aktivitas selama kegiatan pembelajaran berlangsung menggunakan metode eksperimen.

Tahapan Repleksi dilakukan analisis data yang telah diperoleh. Hasil analisis data dipergunakan untuk melakukan evaluasi terhadap proses dan hasil yang ingin dicapai. Repleksi dimaksud untuk mengkaji apa yang telah atau belum terjadi, apa yang dihasilkan, mengapa hal itu terjadi apa yang perlu dilakukan selanjutnya. Hasil refleksi dipergunakan untuk menetapkan langkah selanjutnya untuk menghasilkan perbaikan pada siklus II.

Kegiatan pada siklus II pada dasarnya sama dengan siklus I, hanya saja perencanaan kegiatan berdasarkan pada hasil refleksi pada siklus I, sehingga lebih mengarah pada perbaikan pada pelaksanaan siklus I. Kegiatan pada siklus III pada dasarnya sama dengan siklus I, hanya saja perencanaan kegiatan berdasarkan pada hasil refleksi pada siklus II, sehingga lebih mengarah pada perbaikan pada pelaksanaan siklus II.

Tempat penelitian di SMP Negeri 3 Mataram yang beralamat di Jln. Niaga I No 39 Ampenan pada semester ganjil tahun 2017/2018. Subyek penelitian adalah siswa kelas VIII-3 berjumlah 29 orang terdiri dari laki-laki 14 orang dan perempuan 15 orang. Instrumen yang digunakan dalam penelitian adalah, angket motivasi belajar siswa, catatan hasil observasi selama kegiatan pembelajaran dan dokumentasi. Tehnik pengumpulan data dengan menjumlahkan skor yang diperoleh pada angket dan mengacu pada kriteria yang telah ditentukan. Selanjutnya dianalisis menggunakan perhitungan persentase dengan rumus :

Nilai $=\frac{\text { Jumlah skor yang diperoleh }}{\text { jumlah skor seluruhnya }} \quad \times 100 \%$

Tabel 2. Kriteria motivasi belajar siswa

\begin{tabular}{ccc}
\hline No & Rentang nilai & Kriteria \\
\hline 1 & $80-100$ & Sangat Baik \\
2 & $66-79$ & Baik \\
3 & $56-65$ & Cukup \\
4 & $40-55$ & Kurang \\
5 & $30-39$ & Gagal \\
\hline
\end{tabular}


Untuk mengetahui motivasi belajar siswa maka diamati juga aktivitas pembelajaran selama menggunakan metode eksperimen. Motivasi belajar siswa dikatakan meningkat apabila berada pada rentang amat baik.

\section{HASIL DAN PEMBAHASAN}

Hasil penelitian secara umum menunjukkan bahwa pada siklus I masih terlihat bahwa siswa belum berperan aktif dalam proses pembelajaran dengan menggunakan metode eksperimen. Hal ini disebabkan siswa masih terbawa suasana belajar secara konvensional, dimana siswa hanya bertindak sebagai penerima informasi yang diberikan oleh guru, materi yang disajikan belum mampu menarik minat belajar siswa. Namun pada siklus II sudah ada peningkatan ketertarikan siswa dalam kegiatan pembelajaran, hal ini dapat dilihat dari lembaran angket hasil observasi pada siklus II. Pada siklus III motivasi belajar siswa dengan menggunakan metode eksperimen terjadi peningkatan.

Kegiatan pembelajaran pada siklus I membahas materi pesawat sederhana (sekrup merupakan contoh bidang miring), siswa yang hadir 29 orang. Skor data angket motivasi belajar siswa menggunakan metode eksperimen pada siklus I disajikan pada Tabel 3 .

Tabel 3. Skor rata-rata motivasi belajar siswa pada siklus I

\begin{tabular}{clc}
\hline No & \multicolumn{1}{c}{ Motivasi Belajar Siswa } & Skor yang diperoleh \\
\hline 1 & Perhatian & $50 \%$ \\
2 & Relevansi & $40 \%$ \\
3 & Percaya diri & $75 \%$ \\
4 & Kepuasan & $60 \%$ \\
\hline Jumlah & 225 \\
\hline \multicolumn{2}{l}{ Skor tertinggi } & 56.25 \\
\hline
\end{tabular}

Berdasarkan Tabel 3. motivasi belajar siswa pada siklus I memperoleh skor rata-rata $56.25 \%$. Sedangkan indikator keberhasilan yang telah ditentukan minimal kriteria baik. Adapun kriteria motivasi belajar siswa yang paling tinggi adalah rasa percaya diri sedangkan yang paling rendah adalah relevansi. Menurut data angket motivasi siswa, materi yang dibahas kurang relevan sehingga perhatian siswa kurang fokus untuk kegiatan pembelajaran., begitu pula dengan kepuasan siswa berada pada kriteria cukup. Merujuk pada kriteria yang telah ditentukan maka skor rata-rata yang diperoleh pada siklus I belum memenuhi indikator keberhasilan, sehingga perlu dilanjutkan pada siklus II.

Kegiatan pembelajaran siklus II membahas materi pengungkit, siswa yang hadir 29 orang. Skor data angket motivasi belajar siswa pada siklus II disajikan pada Tabel 4.

Tabel 4. Skor rata-rata motivasi belajar siswa pada siklus II

\begin{tabular}{|c|c|c|}
\hline No & Motivasi belajar siswa & Skor yang diperoleh \\
\hline 1 & Perhatian & $72 \%$ \\
\hline 2 & Relevansi & $78 \%$ \\
\hline 3 & Percaya diri & $60 \%$ \\
\hline 4 & Kepuasan & $65 \%$ \\
\hline \multicolumn{2}{|c|}{ Jumlah } & 275 \\
\hline
\end{tabular}


Skor rata-rata (\%) Jumlah skor yang diperoleh/4 x $100 \quad 275 / 4$ X100 $=68.75 \%$

Berdasarkan Tabel 4 data motivasi belajar siswa diperoleh rata-rata skor $68.75 \%$. Perhatian, relevansi berada pada kriteria baik, kepuasaan siswa mengalami peningkatan berada pada kiteria cukup namun tingkat percaya diri siswa terjadi penurunan berada pada kriteria cukup. Hal ini disebabkan karena setelah melakukan eksperimen peserta didik menganalisa hasil eksperimen menggunakan persamaan (rumus) untuk menghitung keseimbangan pengungkit. Merujuk pada kriteria yang telah ditentukan maka skor rata-rata yang diperoleh pada siklus II belum memenuhi indikator keberhasilan, sehingga perlu dilanjutkan pada siklus III.

Kegiatan pembelajaran pada siklus III membahas materi bidang miring, siswa yang hadir 29 orang. Kegiatan pembelajaran pada siklus III dilakukan berdasarkan hasil refleksi pada siklus II. Adapun skor rata-rata motivasi belajar siswa disajikan pada Tabel 5.

Tabel 5. Skor rata-rata motivasi siswa pada siklus III

\begin{tabular}{lll}
\hline No & Motivasi belajar siswa & Skor yang diperoleh \\
\hline 1 & Perhatian & $84.16 \%$ \\
2 & Relevansi & $80.68 \%$ \\
3 & Percaya diri & $84.70 \%$ \\
4 & Kepuasan & $83.55 \%$ \\
\hline Jumlah & 333.10 \\
\hline Skor rata-rata (\%) Jumlah skor yang diperoleh/ $4 \times$ & $333.10 / 4 \times 100=83.27 \%$ \\
100 & $\%$ \\
\hline
\end{tabular}

Berdasarkan Tabel 5, Motivasi belajar siswa memperoleh rata-rata skor $83.27 \%$. Perhatian, relevansi, percaya diri dan kepuasaan siswa terjadi peningkatan berada pada kriteria amat baik. Merujuk pada kriteria yang telah ditentukan maka motivasi belajar siswa pada siklus III sudah memenuhi indikator keberhasilan, sehingga tidak perlu dilanjutkan pada siklus berikutnya.

Motivasi belajar siswa dengan menggunakan metode eksprimen dari setiap siklus terjadi peningkatan. Adapun perbandingan skor rata-rata motivasi belajar siswa setiap siklus disajikan pada Gambar 2.

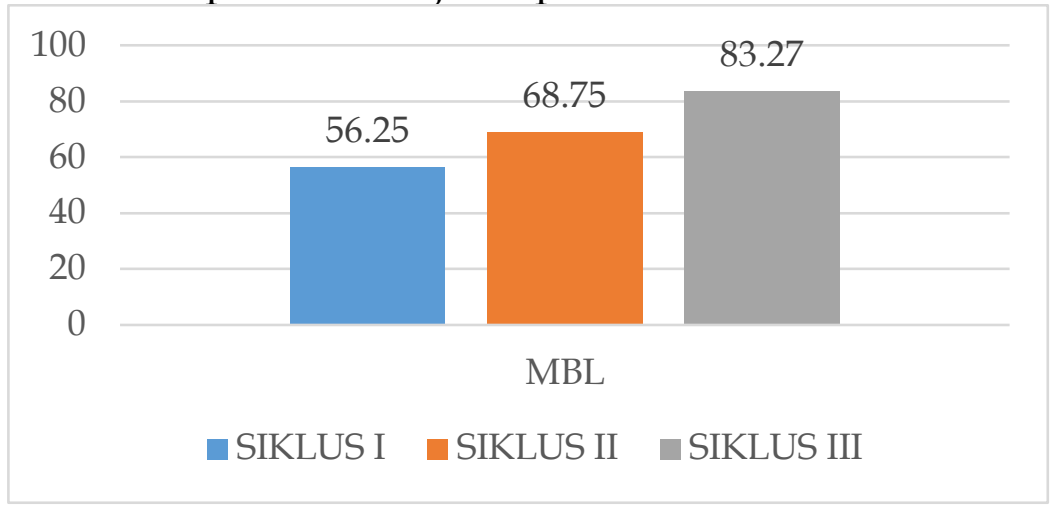

Keterangan: $\quad \mathrm{MBL}=$ Motivasi Belajar Siswa

Gambar 2. Motivasi belajar siswa 
Metode pembelajaran dalam IPA bermacam-macam, salah satunya adalah metode eksperimen. Metode eksperimen dipergunakan di dalam kegiatan pembelajaran untuk lebih mendekatkan siswa pada lingkungan belajar yang sesungguhnya. Siswa dapat melakukan pembuktian berdasarkan teori yang ada bahkan dapat memperoleh hasil yang baru. Dengan demikian akan terjadi perubahan energi dalam diri sesorang yang ditandai munculnya "feeling" (Hamalik, 2001; Miru (2009).

Pelaksanaan pembelajaran menggunakan metode eksperimen dapat terlaksana dengan baik apabila siswa memiliki rasa ingin tahu yang kuat terhadap materi yang akan dipelajarinya. Rasa ingin tahu siswa antara yang satu dengan siswa yang lainya tidaklah sama. Perbedaan inilah yang menjadi salah satu tugas guru untuk mempersempit jurang pemisah, sehingga mendorong tumbuhnya motivasi belajar siswa. Penggunaan metode ekspremen didalam kegiatan pembelajaran telah mendorong siswa untuk melakukan kegiatan-kegiatan sesuai dengan tujuan yang akan dicapai. Hal ini sesuai dengan pendapat Djamarah (2002) dikutip Suranto (2015) bahwa motivasi motor pengerak atau dorongan dalam perbuatan, sehingga siswa yang memiliki motivasi akan bergerak untuk belajar.

Penelitian Tindakan Kelas yang telah dilaksanakan menggunakan metode eksperimen dilakukan tiga siklus. Hasil penelitian penunjukkan setiap siklus mengalami perubahan ke arah perbaikan pembelajaran. Berdasarkan hasil refleksi pada siklus I tahapan metode eksperimen telah dilaksanakan. Namun pada tindakan langkah-langkah metode eksperimen belum dapat terlaksana sesuai dengan alokasi waktu yang ditentukan. Pada kegiatan pembelajaran ini siswa melakukan kegiatan eksperimen secara berkelompok namun tidak semua siswa tertarik untuk melakukan kegiatan eksperimen. Hal ini disebabkan materi yang disajikan kurang menarik sehingga siswa kurang termotivasi untuk melakukan aktivitas. Hal ini dibuktikan hasil angket motivasi belajar siswa yang menunjukkan skor rata-rata $56.25 \%$ berada pada kriteria kurang. Berdasarkan angket tersebut menunjukkan bahwa percaya diri siswa mencapai $75 \%$ sedangkan relevansi memperoleh skor terendah $40 \%$ berada pada kriteria kurang.

Berdasarkan data angket motivasi belajar siswa menunjukkan bahwa materi yang disajikan kurang menarik (kurang relevan). Sehingga pada siklus I, metode eksperimen yang digunakan di dalam kegiatan pembelajaran belum mampu memotivasi siswa. Hal ini sesuai dengan pendapat Sardiman (1998) yang dikutip Rafiqah (2013) fungsi dari motivasi yaitu mendorong manusia untuk berbuat, menuntun arah perbuatan, dan menyelesaikan perbuatan.

Pada siklus II yang dibahas materi pengungkit. Hasil refleksi pada siklus I, metode eksperimen belum mampu meningkatkan motivasi belajar siswa disebabkan kurang menarik materi serta perlu motivasi dan bimbingan dari guru. Untuk meningkatkan motivasi siswa dalam melakukan eksperimen pada siklus II, maka siswa diberi stimulus dengan menayangkan beberapa contoh pengungkit dan contoh cara menganalisis hasil eksperimn serta cara menghitung keuntungan mekanis. Selanjutnya guru memberi kebebasan siswa untuk menentukan sendiri jarak kuasa, sampai dengan menghitung keuntungan mekanis. Rasa ingin tahu siswa mendorong mereka untuk melakukan kegiatan eksperimen sesuai dengan langkah-langkah pada LKPD. Siswa secara bergantian mengukur, mencoba-coba 
alat, dan saling membantu sesama anggota kelompok. Namun untuk mnganalisis hasil eksperimen masih memerlukan bimbingan dari guru. Berdasarkan hasil obeservasi terhadap angket motivasi belajar siswa menunjukkan ada peningkatan skor yaitu skor rata-rata $68.75 \%$ (kriteria cukup). Namun rasa percaya diri siswa terjadi penurunan, skor rata-rata $60 \%$ (kriteria cukup). Hal ini disebabkan kelemahan siswa menganalisis data hasil eksperimen, siswa terkendala dengan hitungan matematis (kali, bagi, kurang, tambah). Sesuai pendapat Dimiyati dan Mujiono (2009) dikutip oleh Sunadi (2013), bahwa salah satu faktor yang mempengaruhi motivasi belajar adalah kemampuan belajar siswa.

Berdasarkan hasil refleksi pada siklus II, kelemahan siswa adalah menghitung atau menganalisis hasil eksperimen yang menyebabkan rasa percaya diri siswa menurun. Pada siklus III siswa dilatih lebih banyak melakukan eksperimen yang disertai analisis hasil eksperimen yang dirancang pada LKPD dengan bimbingan guru. Pada Siklus III yang disajikan adalah materi bidang miring. Kegiatan pembelajaran dirancang cukup fleksibel. Alat dan bahan yang digunakan untuk kegiatan eksperimen diberi kebebasan penuh pada siswa, namun merujuk pada konsep bidang miring. Pada siklus III siswa lebih antusias untuk melakukan eksperimen. Beberapa kelompok siswa memilih melakukan kegiatan eksperimen di luar ruangan. Alat dan bahan yang digunakan untuk menghitung bidang miring bervariasi. ada yang menggunakan buku yang dimiringkan pada tangga, ada yang menggunakan triplek, siswa sudah terlihat lebih terampil untuk mengukur bidang miring. Hal ini menunjukkan motivasi belajar siswa cukup tinggi sehingga muncul kreativitas belajar siswa. Sesuai dengan pendapat Hamalik (2001) yang dikutip oleh Miru (2009) bahwa motivasi ekstrinsik adalah energi yang berfungsi karena adanya rangsangan dari luar untuk melakukan sesuatu.

Kegiatan pembelajaran menggunakan metode eksperimen pada siklus III memperlihatkan motivasi belajar siswa cukup tinggi, akan tetapi untuk menganalisis data masih memerlukan bantuan, karena tidak semua siswa mempunyai kemampuan sama untuk menganalisis hasil eksperimen mereka, guru membantu siswa yang masih lambat dalam menganalisis data. Pada siklus III ini anggota kelompok yang berkemampuan tinggi diberdaya oleh guru untuk membantu siswa lainnya. Antusias siswa untuk dapat menyelesaikan tugas cukup tinggi, siswa berulangkali menanyakan cara menganalis (menghitung) hasil eksperimen sampai memperoleh hasil yang benar. Hal ini didukung hasil observasi angket motivasi belajar siswa. Skor rata-rata motivasi belajar siswa pada siklus III 83.27\% (amat baik). Aspek motivasi yaitu perhatian, relevansi, percaya diri dan kepuasaan berada pada kriteria amat baik. Merujuk pada indikator keberhasilan yang ditentukan maka telah memenuhi kriteria yang ditentukan. Sesuai pendapat Mujiono (2009) dikutip Sunadi (2013) bahwa faktor yang mempengaruhi motivasi adalah kemampuan untuk belajar dan upaya guru dalam membelajarkan siswa.

\section{KESIMPULAN}

Berdasarkan hasil penelitian ini dapat disimpulkan bahwa Metode ekperimen dapat meningkatkan motivasi belajar siswa 


\section{SARAN}

Metode eksperimen dapat digunakan dalam kegiatan pembelajaran untuk memberi pengalaman nyata kepada siswa. Metode eksperimen yang digunakan dalam kegiatan pembelajaran mampu meningkatkan motivasi belajar siswa, namun masih perlu bimbingan dalam hal menganalisis data yang menggunakan rumus matematis. Sebagai acuan bagi guru yang akan melakukan Penelitian Tindakan Lanjutan, khusus bagi guru MIPA dan IPS terpadu dapat mencoba metode ekperimen untuk melatih keterampilan matematis siswa.

\section{DAFTAR PUSTAKA}

Apriliya, S. (2007). Manajemen Kelas untuk Menciptakan Iklim Belajar yang Kondusif. Jakarta Timur: PT Visisndo Media Persada

Juliansya, T. (2010). Mengajar Tanpa Bosan: Kiat-kiat Terbaik untuk Guru. Bandung: PT Setia Purna Inves

Kusnandar. (2007). Guru Profesional Implementasi Kurikulum Tingkat Satuan Guruan (KTSP) dan Persiapan Menghadapi Sertifikasi Guru. Jakarta: Raja Grafindo Persada

Kusnandar. (2008). Guru Profesional Implementasi Kurikulum Tingkat Satuan Guruan (KTSP) dan Persiapan Menghadapi Sertifikasi Guru. Jakarta: Raja Grafindo Persada

Miru A. S., (2009). Hubungan antara motivasi belajar terhadap prestasi belajar mata diklat Instansi Listrik siswa SMK Negeri 3 Makasar. Jurnal MEDTEK, VOLUME 1 NO 1 APRIL 2019

Pour, D., N., Herayanti, L., \& Sukroyanti, B., A. (2018). Pengaruh Model Pembelajaran Talking Stick terhadap Keaktifan Belajar Siswa. Jurnal Penelitian dan Pengkajian Ilmu Pendidikan: e-Saintika, 2(1), 36-40.

Rafiqah M., Yusmansyah., Mayasari, S. (2013). Pengaruh Motivasi Belajar Terhadap perestasi belajar siswa kelas XI IPS SMA Negeri 2 Metro tahun pelajaran 2012/2013.

Sriwahyuningsih, D., Ahzan, S., \& Habiburrahman, L. (2018). Pengaruh Model Pembelajaran Koperatif Tipe Make A Macth dengan Permainan Rangking One Physical Terhadap Motivasi dan Hasil Belajar Siswa. Jurnal Penelitian dan Pengkajian Ilmu Pendidikan: e-Saintika, 2(1), 29-35.

Sunadi L. (2013). Pengaruh Motivasi Belajar dan Pemanfaatan Fasilitas Belajar Terhadap Prestasi Belajar Siswa Pada Mata Pelajaran Ekonomi Kelas XI IPS di SMA Muhammadiah 2 Surabaya. Jurnal guruan ekonomi.

Suranto. (2015). Pegaruh motivasi, suasana lingkungan dan saran prasarana belajar terhadap prestasi belajar sisa (Studi Kasus pada SMA Khusus Putri di SMA Islam Dipenogoro Surakarta). Jurnal Ilmu Sosial Vol 25 No 2 Desember 2015.

Wardhana, Y. (2010). Teori Belajar dan Mengajar. Bandung: PT. Pribumi Mekar. 